\title{
Can Supplier Governance Improve Sustainable Performance of Manufacturing Firms?
}

\author{
S. Sapukotanage ${ }^{1}$, B. N. F. Warnakulasuriya ${ }^{2}$, S. T. W. S. Yapa ${ }^{2}$ \\ ${ }^{1}$ The Open University of Sri Lanka, Sri Lanka \\ ${ }^{2}$ University of Sri Jayawardenapura, Sri Lanka \\ Correspondence: S. Sapukotanage, The Open University of Sri Lanka, Sri Lanka \\ Received: September 20, 2017 \\ doi:10.5539/ibr.v10n12p97
}

\begin{abstract}
Establishing relationships with suppliers has been found critically important for manufacturing organizations in meeting the challenges faced by them for maintaining sustainability in global supply chains. At the same time, managing these relationships so formed, by way of governance strategies is considered equally important in ensuring positive outcomes through the relationships established. This assertion of acquiring positive outcomes through managed relationships, suggested by the transaction cost theory was tested using data from the apparel manufacturing and exporting industry of Sri Lanka in relation to the sustainable performance of manufacturing firms. The results revealed that supplier governance negatively influences the relationship between sustainable practices and sustainable performance of manufacturing firms in the apparel manufacturing and exporting industry of Sri Lanka indicating that governance strategies do not always bring positive outcomes. These findings contribute to the knowledge by providing evidence as to the viability of governance mechanisms in achieving positive outcomes through buyer-supplier relationships in the context of developing countries.
\end{abstract}

Keywords: inter-organizational relationships, supplier governance, supply chain, sustainable performance

\section{Introduction}

In the recent years formation of inter-organizational relationships for the benefit of one another is dramatically increasing (Mellewigt et al. 2007). Supply chain is such a formation of inter-organizational relationships developed for the mutual benefit of organizations. As firms become dependent on resources that are scarce their coordination with other members of the supply chain increases.

The relationship that a manufacturing organization builds with its suppliers, for accruing such benefit can be identified with the inbound function of the supply chain (Rao and Holt, 2005). Such relationships that manufacturers form with their suppliers are found important in achieving sustainable performance. This has made many manufacturers to ensure that the material supplied by their suppliers satisfy the sustainability requirements.

Krause and Ellram (1997) explain that a company cannot be expected to be sustainable if their suppliers are not sustainable, highlighting the importance of suppliers in ensuring sustainability along supply chains. Moretto etal. (2012) have also identified that the source of environmental and ethical risks of many customer companies are their suppliers. Liker and Choi (2004) explain that businesses tend to find their suppliers important in ensuring a cost lower than the vendors of their rivals as well as in improving quality and de veloping new processes and products. As a result, manufacturers (buyers) show an interest in managing their suppliers when maintaining relationships with them along the supply chain to make sure that sustainability concerns are satisfied (Coxetal. 2004).

All parties to an economic exchange are expected to gain from their collective operation (Granovetter, 1985).Although the mutual and well balanced dependence between two parties to an exchange are expected to help form strong relationships, when there are imbalances in the mutual dependence the trust between parties can be damaged while sometimes creating conflicting situations (Bitran et al., 2006). This highlights that inter-organizational alliances come with potential hazards (Rowley et al. 2000). Governance is the mechanism through which such uncertainty is reduced (Grover and Saeed, 2007). It involves control and coordination. Wathne and Heide (2004) argue that where there is no governance exercised in upstream relationships it will 
negatively influence the manufacturer's ability to respond to uncertainty in the downstream market. Carey and Lawson (2011) too share a similar view when they say that the performance of the supply chain can be improved with the social capital built up through enhanced supplier relationships (Nahapiet and Ghoshal, 1998). The implication is that without mitigating the uncertainty in the relationships with the suppliers a firm is unable to meet the expectations of their customers (Carey and Lawson, 2011).

Accordingly, supplier governance can be expected to bring positive outcomes to the manufacturer in his transactions with the supplier. On this ground, the researcher argues that if sustainable performance of manufacturing organizations is attributed to an outcome of social capital formed through supplier relationships (since social capital is the result of cognitive, relational and structural capital), through the application of supplier governance those organizations should be able to improve their sustainable performance. Sustainable performance is an outcome of sustainable practices. Therefore, it is reasonable to expect supplier governance to have a positive moderating effect on the relationship between these sustainable supply chain practices and sustainable performance of manufacturing organizations. Although there are many organizations in the South Asian region that have undertaken significant efforts towards establishing sustainable supply chain management initiatives, the researcher found that no previous research has tested an empirical link between how supplier governance could impact such efforts and resultant subsequent improvements in sustainable performance. Therefore it is important to address the role of supplier governance for bringing about favourable results from the relationship between the supplier and the focal manufacturing firm in achieving sustainable performance through sustainability initiatives. Present study addresses this need of identifying how a manufacturing firm gets the benefit of supplier relations towards achieving sustainable performance through supplier governance by examining the moderation effect of supplier governance. This paper presents the results of a survey conducted among apparel manufacturing and exporting organizations in Sri Lanka to address the above need.

The paper begins by presenting the theoretical foundation for understanding governance mechanisms in inter-organizational relations. Then it presents the conceptual model developed to test the moderation effect of supplier governance. It is followed by outlining the methodology employed to empirically test the conceptual model. The findings are tested using variance based structural equation modelling (PLS) with Smart PLS 3.0. The paper concludes with an analysis of the impact of governance mechanisms used by apparel manufacturing and exporting firms of Sri Lanka to manage their suppliers, in moderating the relationship between sustainable supply chain practices they adopt and the resulting sustainable performance.

\section{Theory on Governance Mechanisms}

The general understanding of theory on governance is that the characteristics of transactions translate into exchange hazards, which might be managed through governance. There are explanations in literature emphasizing the use of governance as a mechanism for reducing risk of opportunism as well as a coordinating tool against exchange hazards.

The mechanisms used to govern relationships have been categorized in literature as contractual governance (governance through formal contracts) and relational governance (governance based on trust) depending on the above stated nature of governance exercised. Contractual governance relies on the use of formalized, legally binding agreements to govern the buyer-supplier relationship (Zhao et al., 2008, Carey and Lawson, 2011). They include the formal contracts which include the promises or obligations to perform particular actions in the future (Espallardo et al., 2010). Here the parties to the exchange predict the potential hazards and define remedies for foreseeable contingencies (Poppo and Zenger, 2002). In relational governance, relational norms such as trust is expected to operate as a self-enforcing safeguard against inherent hazards. Trust and formal contracts have been identified as both substitutes and complements when they are considered as governance mechanisms. Whatever the way governance mechanisms are identified they are expected to make the governance possible by way of either control or coordination. In strategic management, transaction cost economics and the resource-based view are two theoretical perspectives that have been prominent in understanding the governance of inter organizational relations which aims at mitigation of opportunism and misappropriation of value by either parties in their relationships with other parties to an exchange. Transaction Cost Theory addresses both the controlling and coordination purposes sought by governance mechanisms in terms of contractual and relational governance. It promotes the idea that governance mechanisms serve the purpose of controlling when the parties to an exchange are well aware of its operation and thus reducing the transaction costs associated with it. The costs involved in engaging in activities that are not favourable to either party are minimized when the terms and conditions are laid down clearly. It could also be argued that when a formal contract exists it improves the understanding between the parties, enabling the buyer and the seller to strengthen relational governance. 


\section{The Conceptual Model}

A conceptual model was developed in this study based on literature to empirically test the moderating impact of above said governance in relation to suppliers in buyer-supplier relationships. It was developed mainly based on the argument that when an individual member of a supply chain works in collaboration with another member they can move towards better performance. The researcher found the roots of this argument embedded in the social capital theory whereby the social connections in a network are supposed to bring positive outcomes for member firms (Nahapiet and Ghoshal, 1998). Accordingly, forming such relationships with suppliers in the supply chain network should provide an added advantage to the organization.

The conceptual model developed for the purpose of the present study, based on the above argument contains three constructs: supplier governance, sustainable supply chain practices and sustainable performance. The independent variable in this model is the sustainable supply chain practices. Sustainable performance is taken as the dependent variable. Since the magnitude of supplier governance is expected to moderate the impact of sustainable supply chain practices on the sustainable performance (explained in the agency theory and Transaction Cost Economics) the supplier governance becomes the moderator variable.

Although sustainable supply chain practices have been discussed in many research studies before, the framework suggested by Beske and Seuring (2014) provides a sound classification of dimensions. With the dimensions introduced by Beske and Seuring (2014) researcher could identify sustainable supply chain practices as a multidimensional construct. Law et al. (1998) explain that the dimensions of a multidimensional construct can be conceptualized under an overall abstraction and it is theoretically meaningful and parsimonious to use this overall abstraction as a representation of the dimensions. Therefore the researcher treats sustainable supply chain practices as a multidimensional construct consisting of the dimensions identified by Beske and Seuring (2014). The application of the Triple Bottom Line approach is not evident in the previous studies in conceptualizing sustainability. Present study analyses sustainable performance as a multidimensional construct consisting of environmental, economic as well as social performance. Supplier governance also is identified in a hybrid governance (plural form of governance) structure (Cai et al., 2009) with contractual governance and relational governance as dimensions.

\subsection{Sustainable Performance}

The impact of an organization's activities on air, water and energy are identified to reflect the environmental performance. Social performance is measured in terms of the impact of an organization's activities on the communities (Schaltegger and Burritt 2014). Economic performance of an organization is its financial achievement. Therefore, in the present study an organization is considered sustainable in its performance if it was able to produce satisfactory results in all the three areas of performance reflected by the above indicators (Triple Bottom Line approach).

\subsection{Sustainable Supply Chain Practices}

The sustainable practices identified and discussed in literature are introduced under a set of five broad headings (umbrella terms) by Beske and Seuring (2014) in a piece of more recent scholarly work. They identify these five broad headings as 'categories'. They are orientation, continuity, collaboration, risk management and pro-activity directed at sustainability of organizations. This classification has been done taking in to consideration the relationship of each practice to the strategy of an organization, its structure and the processes involved. The sustainable practices that are linked to the strategic level of an organization are the orientation towards the triple bottom line and supply chain management. These are listed under the broad category of 'orientation'. The structure related practices are categorized as 'continuity' which involves long term relationships, supply chain partner selection and partner development. Risk management and pro-activity are the categories of sustainable practices related to the processes of an organization. Selective monitoring, standards and certification and identifying pressure groups are the practices related to risk management. Learning, stakeholder management, innovation and life cycle assessment are identified as pro-activity related practices of sustainability. Collaboration is related both to the structure as well as the processes. Technological integration, logistical integration, enhanced communication and joint development are the practices related to collaboration.

\subsection{Supplier Governance}

The moderating variable supplier governance was defined based on a literature review to include both contractual and relational mechanisms used by manufacturing organizations for proper control and coordination of their relationships with supplier.

Contractual governance includes relying on the use of formalized, legally binding agreements to govern the 
buyer-supplier relationship (Zhao et al., 2008, Carey and Lawson, 2011). Relational governance is identified as the self-enforceability of restraining opportunistic behavior of suppliers, relying on social sanctions for restraining deviant behavior of suppliers. This also includes a mutually beneficial re-adjustment/ renegotiation process that is cooperative.

All the above major constructs that constitute the conceptual model; sustainable performance, supplier governance and sustainable supply chain practices are multidimensional. At the same time, the constructs representing the main dimensions are manifestations of the main construct (Jarvis et al., 2003). Therefore, the researcher specifies the proposed conceptual model shown in Figure 1 formed with the above constructs as a second-order reflective hierarchical model (Akter et al., 2010, Wetzels, 2009). One of the significant advantages of hierarchical modeling is that it allows for more theoretical parsimony and less model complexity (Law et al., 1998).

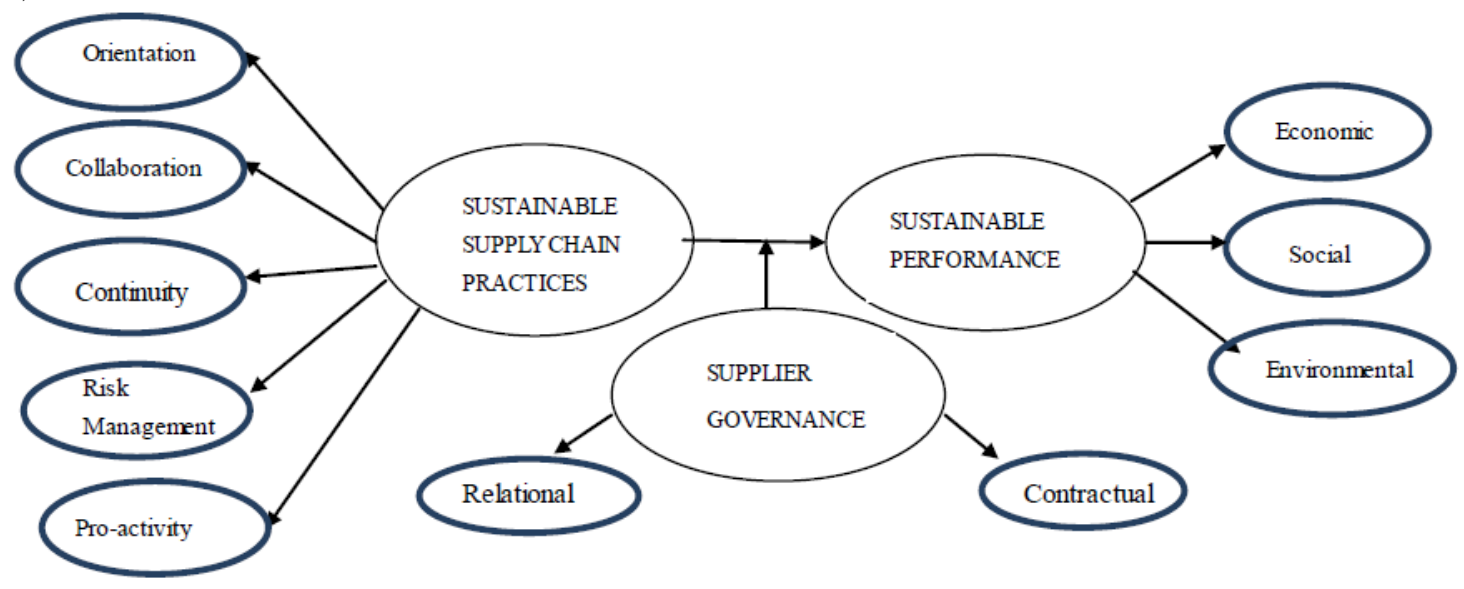

Figure 1. The Conceptual Model

\section{Hypotheses Development}

To embed the hierarchical model in a nomological network, the sustainable supply chain practices and supplier governance constructs were framed with the outcome construct sustainable performance through the development of hypotheses.

\subsection{Sustainable Supply Chain Practices and Sustainable Performance}

Carter and Rogers (2008) showed that firms strategically undertaking Sustainable Supply Chain Management can achieve higher economic performance than firms that pursue only one or two of the three components of the triple bottom line. Moretto et al. (2012) found that in the Italian fashion industry innovation performance in terms of sustainability could be improved through sustainable practices. Organizations that participate in environmental protection and fulfill social responsibility have been found to be compensated by an increase in long-term benefits (Brammer \& Millington, 2008). At the same time, it is argued in literature how higher economic benefits empower corporations to take greater social responsibility. Those who are economically strong have been found to be capable of spending more money on pollution treatment, provide more benefits for society, and improve the welfare of their employees (Cao \&Zhang, 2011). These explanations highlight a positive relationship between sustainable supply chain practices and sustainable performance. In explaining the positive relationship between sustainable supply chain practices and sustainable performance, the latter is calculated only in relation to environmental performance in many instances. Although it is the environmental performance or any other dimension that is considered to be 'sustainable performance' in literature, it is important to understand the relationship that exists between sustainable supply chain practices and sustainable performance considering all three dimensions of the Triple Bottom Line. The relationships that have been already identified in literature also have rarely focused on the developing countries. Rao and Holt (2005) explained the necessity of conducting similar studies in different countries to enable comparison. This gap in literature leads to a research question.

\section{Research Question 01}

What is the relationship between the adoption of sustainable supply chain practices and sustainable performance of individual organizations in the apparel manufacturing and exporting industry of Sri Lanka?

A relational hypothesis is developed to address this question.

H1: The higher the level of adoption of sustainable supply chain practices, the higher the level of sustainable 
performance of individual firms in the apparel manufacturing and exporting industry of Sri Lanka.

\subsection{Supplier Governance and Sustainable Performance}

Verdecho et al. (2012) highlighted the fact that proper understanding of collaborative implications is often overlooked and this has caused collaborative relationships to fail. The explanation of Seuring and Muller (2008) that "supplier management for risk and performance" is necessary in meeting the sustainability needs emphasized by external triggers confirms the importance of a proper understanding of collaborative relationships. The importance of relational contract for supplier -buyer relationship which in turn affects supply chain performance has been emphasized by Chuah et al. (2010). Based on the predictions of Transaction Cost Analysis (TCA), Wathne and Heide (2004) explain that governance can improve focal company's performance. These authors have clearly identified sustainable performance to result from supplier evaluation, selection and development. They argue that the risks regarding social and environmental sustainability may be mitigated by the application of above strategies. Carter and Rogers (2008) explain that firms that are dependent upon external resources can improve their economic sustainability through vertical coordination indicating that working closely with suppliers can lead to sustainable performance.

But how the governance structure influences sustainable performance is also an area that has not been covered by literature. Therefore a gap is created as to how supplier governance can affect the sustainable performance of organizations leading to another research question. In the present study this gap in literature is addressed in relation to a developing country.

\section{Research Question 02}

What is the impact of supplier governance practices on the sustainable performance of individual firms in the apparel manufacturing and exporting industry of Sri Lanka?

Relational hypothesis $\mathrm{H} 2$ is developed to address this question.

$\mathrm{H} 2$ : The higher the level of application of supplier governance practices, the higher the level of sustainable performance of individual firms in the apparel manufacturing and exporting industry of Sri Lanka.

4.3 Supplier Governance Practices towards the Relationship between Sustainable Supply Chain Practices and Sustainable Performance

The summary of the previous explanations is that buyer- supplier relationships involve risks and uncertainty and supplier governance is a preventive mechanism. Therefore it is important to know how supplier governance can moderate the relationship between the sustainable supply chain practices and sustainable performance of individual apparel manufacturing and exporting firms since the implication of Transaction Cost Theory is that governance mechanisms bring better outcomes for the parties to a contract. The researcher found no previous studies that focused on studying this relationship. Literature could not be traced to empirically support this relationship. Therefore, a research question is formed to address this gap.

\section{Research Question 03}

What is the impact of supplier governance practices towards the relationship between sustainable supply chain practices and sustainable performance of individual firms in the apparel manufacturing and exporting industry of Sri Lanka?

Relational hypothesis H3is developed to address this question.

H3: The higher the level of supplier governance the better will be the relationship between sustainable supply chain practices and sustainable performance of individual firms in the apparel manufacturing and exporting industry of Sri Lanka.

\section{Methodology}

\subsection{Sampling}

Data for this study was collected from the apparel manufacturing and exporting industry of Sri Lanka. There were two specific reasons behind the selection of the apparel manufacturing and exporting industry to represent the sample. First being the availability of clearly identified buyer - supplier relationships in the supply chains in which these firms are members. The second reason was that the organizations in this industry operate in the global network where sustainability is a major requirement for survival. The sampling unit of the study included individual organizations in this industry. A person at the management level of each of these organizations was identified to respond to the questionnaire. 


\subsection{Data Collection}

A pre-designed questionnaire was used as the research instrument to collect the data required for the study.154 apparel manufacturing and exporting organizations of Sri Lanka responded to the questionnaire.

The questions in the research instrument were based on the indicators of each dimension of the second order constructs identified from the literature review and purified after a pilot test [Statistical Package for Social Science (SPSS) was used for data cleaning and preliminary analysis before the final 154 cases were analyzed using Partial Least Squares - Structural Equation Modelling (PLS-SEM)].

Sustainable Performance consisted of 11 indicators (environmental performance3, social performance 5 and economic performance 3). Sustainable supply chain practices had 28 indicators (orientation 4, continuity 9 , collaboration 2, risk management 7 and pro-activity 8).The moderating variable supplier governance had 7 indicators (contractual governance 3 and relational governance 4). The perceptual evaluations of the respondents for the indicators of sustainable supply chain practices and supplier governance were measured in a structured format on a five-point Likert-type scale, ranging from "strongly agree" to "strongly disagree." The five-point scale used to measure the perceptual evaluations for sustainable performance ranged from "strong positive variations" to "strong negative variations." The measurement scale of the present study used to measure perceptual evaluations of the respondents assigned a score of ' 1 ' if the respondents strongly agreed to the statements presented by the researcher.

\subsection{Data Analysis Strategy}

The researcher needed to establish rigor in the present study since the model explains something that is poorly or imperfectly understood beforehand. This necessitated to enable the researcher to discover the regularities that will allow adequate prediction of sustainable performance of organizations and the role of supplier governance. Variance based SEM (PLS) is found more suitable for studies that are relatively complex and the phenomenon under study is new or changing(Hair et al., 2012).At the same time since each of the constructs in the model were multidimensional, in selecting the analysis strategy, the ability of it to address complex models was also a consideration. Variance based SEM (PLS) enables analysis of models consisting of constructs involving more than one dimension when indicators are manifestations of constructs (Wilson, 2010, Hair et al., 2012). In addition, PLS-SEM was also suitable due to the integration of a newly-introduced construct (sustainable performance addressing the triple bottom line) to the model, that was seldom being examined in previous studies (Afthanorhan, 2013). Besides the examination of direct effect between sustainable supply chain practices and sustainable performance, researcher was more interested in understanding the moderating effect of supplier governance. The identification and quantification of moderating effects in complex causal structures could be analyzed by means of Partial Least Squares Path Modeling (Henseler and Fassott, 2010, Henseler and Chin, 2010, Hair Jr. et al., 2016). These reasons lead the researcher to use variance based SEM (Partial Least Squares) path modelling for analyzing the collected data.

\section{Results}

\subsection{Role of Suppliers in the Apparel Exporting Industry of Sri Lanka}

Before explaining the role of supplier governance the researcher found it important to explain the role of suppliers in the apparel exporting industry of Sri Lanka. In order to collect data for this purpose there were a few close ended questions presented to the respondents in the main survey. These data revealed that all firms were dealing with local as well as overseas suppliers, More than $50 \%$ of the fabric used for manufacturing was obtained from overseas suppliers. The other raw materials obtained from suppliers were thread, packing material, dye, chemicals, accessories etc. Table 1 summarizes the type of suppliers that the apparel manufacturers buy raw materials from and the materials that they obtain from them.

Table 1. Type of Supplier and Materials Obtained

\begin{tabular}{ccccccc}
\hline & Fabric & Thread & Dye & Chemicals & Packing material & Other \\
\hline Overseas & $75 \%$ & $20 \%$ & $22 \%$ & $05 \%$ & $30 \%$ & - \\
Local & $25 \%$ & $80 \%$ & $78 \%$ & $95 \%$ & $60 \%$ & - \\
\hline
\end{tabular}

The-respondents were required to state whether they consider it important for their suppliers to be sustainable. The opinion of each of the respondents was that they need to be. Then the respondents were asked why they consider it important. The responses for the reasons given were as shown in Table 2. 
Table 2. Reasons for Considering Supplier Sustainability Important

\begin{tabular}{|c|c|c|c|c|c|}
\hline & $\begin{array}{l}\text { Strongly } \\
\text { Agree }\end{array}$ & Agree & $\begin{array}{l}\text { Neither agree nor } \\
\text { disagree }\end{array}$ & Disagree & $\begin{array}{l}\text { Strongly } \\
\text { Disagree }\end{array}$ \\
\hline $\begin{array}{l}\text { To ensure the chemicals used in the fabric are not } \\
\text { hazardous }\end{array}$ & & $98 \%$ & $02 \%$ & & \\
\hline $\begin{array}{l}\text { Customers will assess us on our sustainability } \\
\text { Sustainable practices of suppliers will affect the } \\
\text { quality of our output }\end{array}$ & $80 \%$ & $\begin{array}{c}19 \% \\
100 \%\end{array}$ & $01 \%$ & & \\
\hline $\begin{array}{l}\text { Choosing sustainable suppliers will build our } \\
\text { image in the customer }\end{array}$ & $95 \%$ & $05 \%$ & & & \\
\hline
\end{tabular}

The responses of the participants when they were asked what should be done to maintain the sustainable behavior of suppliers were as shown in Table 3.

Table 3. Mechanisms for Ensuring Supplier Sustainability

\begin{tabular}{|c|c|c|c|c|c|}
\hline & $\begin{array}{l}\text { Strongly } \\
\text { Agree }\end{array}$ & Agree & $\begin{array}{c}\text { Neither agree nor } \\
\text { disagree }\end{array}$ & Disagree & $\begin{array}{l}\text { Strongly } \\
\text { Disagree }\end{array}$ \\
\hline Bind with legal contracts & $65 \%$ & $35 \%$ & & & \\
\hline Apply monetary sanctions against them & & $18 \%$ & $82 \%$ & & \\
\hline $\begin{array}{l}\text { Maintain close relationships with suppliers } \\
\text { enabling self- enforceability }\end{array}$ & $76 \%$ & $34 \%$ & & & \\
\hline Develop a mutual understanding with the supplier & $70 \%$ & $30 \%$ & & & \\
\hline
\end{tabular}

The descriptive statistics related to supplier governance helped in understanding the types of practices adopted and their level of adoption. It was interesting to find that none of the firms were confined to practice solely one type of governance. Rather all of them were practicing a combination of the two types of practices at different rates. The mean value for level at which the supplier governance was practiced in the apparel exporting industry of Sri Lanka was 1.93. This was a mean value closer to ' 2 '. It was an indication that supplier governance was prevalent in the apparel exporting industry of Sri Lanka at a considerable level. When the responses for individual dimensions were examined contractual governance could be observed with a mean value of 1.94 . The descriptive statistics in relation to relational governance was a mean value of 1.90 . It is clearly evident from these statistics that the apparel exporters of Sri Lanka rely more on relational governance in managing their suppliers than exercising contractual governance.

These statistics are shown in Table 4.

Table 4. Descriptive Statistics for Supplier Governance

\begin{tabular}{cc}
\hline Type of Governance & Mean \\
\hline Overall & 1.93 \\
Contractual & 1.94 \\
Relational & 1.90 \\
\hline
\end{tabular}

Further a one sample T-Test was carried out in order to compare means. For this, decision criteria were developed as the data was 'interval'. Accordingly an Assumed Mean of 1-2.49 was considered high, 2.5-3.49 considered moderate and 3.5 and above as low. According to the data collected the observed mean for supplier governance was 1.93 which falls between 1 and 2.49 of the decision criteria. This level of adoption could be considered as high according to the decision criteria. The $t$-statistic for this test to examine the difference between the observed and the assumed means was found significant proving that the level of application of supplier governance is high among individual firms in the apparel exporting industry of Sri Lanka.

The One sample T- Test carried out for the responses of apparel exporters of Sri Lanka, for Sustainable supply chain practices as well as Sustainable performance also revealed their existence at 'high' levels. This confirmed the researcher that it is reasonable to use the data collected for further analysis. PLS 3.0 software was used to do the variance based structural modeling in analyzing the relationships hypothesized at the outset of the study.

\subsection{Model Specification}

Before running the PLS analysis with Smart PLS 3.0 software, the model was specified enabling the researcher to distinguish between the measurement model which related constructs to their measures and the structural model which related the constructs to each other. In constructing the measurement model for this study it was important for the researcher to distinguish between the latent constructs and the manifest variables (their measures).Since all the constructs in the conceptual model are multi- dimensional the dimensions of the main constructs are identified as first order constructs and they become manifestations of the second order constructs. Since constructs of this study are linear combinations of their measures the researcher identified the Principal Factor (Reflective) model suitable for the present study (Bollen and Lennox,1991, Bollen, 2002). In otherwords 
the co-variation among measures is caused by and therefore reflects variation in the underlying latent factor (Jarvis, et al., 2003). A model was developed to show these relationships where the second order constructs that contained all indicators of first order constructs were identified with the repeated indicator approach (Wilson,2010, Wetzels, et al.,2 009, Akter et al., 2010).The detailed procedure of constructing the path model using Smart PLS 3.0 is explained below.

(1) Constructing the first-order latent variables (LV) and relating them to their respective manifest variables using reflective outer model.

(2) The second-order latent variables were constructed by relating them to the underlying first-order latent variables using reflective outer model. For the second order latent variable sustainable supply chain practices (SUSPRAC), the first order latent variables were orientation (ORI), continuity (CON), collaboration (COL), risk management (RISM) and pro-activity (PRO). For the second order latent variable sustainable performance (SUSP), the first order latent variables were environmental performance (ENVP), economic performance (EP) and social performance (SOCP). For the second order latent variable supplier governance (SUSGOV), the first order latent variables were contractual governance (CONGOV) and relational governance (RELGOV).

\subsubsection{Assessment of the Measurement Models at the Item Level and Higher-Order Level}

Hierarchical model so developed was then estimated using PLS path modeling. Estimates for thefirst-order loadings, second-order loadings and structural parameters could be obtained from this exercise. A nonparametric bootstrapping procedure was used to obtain standard error and calculate t-statistics for inferential purposes. The psychometric properties of the latent variables and the structural relationships were then assessed using the estimates obtained.

\subsubsection{Assessing the First Order Constructs}

Assessment of reflective measurement models includes examining composite reliability to evaluate internal consistency, individual indicator reliability, and average variance extracted (AVE) to evaluate convergent validity. In addition, the Fornell-Larcker criterion and cross loadings are used to assess discriminant validity (Chin 1998, 2010, Hair et al., 2012, Henseler et al., 2015, 2016, Gefen and Straub, 2005, Mulaik, 2009, Hair et al., 2013).

The exercise of assessing the above mentioned psychometric properties (validity and reliability) of the measurement model of this study was exercised by performing the Confirmatory Factor Analysis (CFA). The unidimensionality and internal consistency of the measures, were the first properties to be assessed. Data presented in Table 5 confirms the unidimensionality of the latent variables. Having confirmed the unidimensionality, composite reliability and Cronbach alpha, the obtained values were compared against the standard values of 0.70 (Hair etal., 2012, Cronbach, 1951). As shown in Table 5 these values relating to the latent constructs of the model met the threshold levels demonstrating the internal consistency. Convergent validity of the measures is evaluated by the value for Average Variance Extracted of each construct (Fornell and Larcker, 1981). According to Chin (1998) the AVE value of each construct should be 0.50 or more. Thus the Convergent validity for the measures was confirmed since the AVE exceeded the threshold value of 0.5.Discriminant validity was adequately demonstrated as all the PLS indicators load much higher on their hypothesized factor than on other factors (own loading are higher than cross loadings)(Chin 1998, 2010,Hair et al., 2012, Henseler et al.,2015,2016, Gefen and Straub, 2005, Mulaik, 2009, Hair et al., 2013). The Fornell and Larcker (1981) criteria was also satisfied by the first order constructs ensuring discriminant validity as shown in Table 6.

Table 5. Psychometric Properties of the First Order Constructs

\begin{tabular}{|c|c|c|c|c|c|}
\hline Construct & Item & Loading & $\begin{array}{l}\text { Cronbach } \\
\text { Alpha }\end{array}$ & CR & AVE \\
\hline \multirow[t]{4}{*}{ Orientation } & $\begin{array}{l}\text { o1. Top management provides support for reaching sustainability in the } \\
\text { supply chain. }\end{array}$ & 0.815 & \multirow{4}{*}{0.884} & \multirow{4}{*}{0.920} & \multirow{4}{*}{0.743} \\
\hline & $\begin{array}{l}\text { o2. There is integration of sustainability in the organization's strategy and } \\
\text { strategy formulation. }\end{array}$ & 0.907 & & & \\
\hline & $\begin{array}{l}\text { o3. There is dis semination and acceptance of sustainability } \\
\text { values throughout the company. }\end{array}$ & 0.847 & & & \\
\hline & $\begin{array}{l}\text { o4. Integration of supply chain management thinking and } \\
\text { goals into day to day management is present. }\end{array}$ & 0.875 & & & \\
\hline \multirow[t]{5}{*}{ Continuity } & con1. Management takes a considerable effort towards & 0.837 & \multirow{5}{*}{0.944} & \multirow{5}{*}{0.952} & \multirow{5}{*}{0.690} \\
\hline & $\begin{array}{l}\text { maintaining a reasonable quality of life among supply } \\
\text { chain partners }\end{array}$ & & & & \\
\hline & con2. Engages in Supplier development Shares common & 0.817 & & & \\
\hline & goals and structures with suppliers. & & & & \\
\hline & con3. Values trust as an important component Supplier & 0.816 & & & \\
\hline
\end{tabular}


base is reduced to maintain satisfactory partners.

con4. Managing relationships with strategic suppliers is $\quad 0.884$

considered important.

con5. Maintains transparency. $\quad 0.861$

con6. Regular inter-departmental and inter-organizational $\quad 0.756$

meetings are held.

con7. Shares common goals and structures with suppliers. $\quad 0.832$

con8. Maintain mutually beneficial relationships sharing $\quad 0.834$

risks and profits.

con9. Suppliers are informed of changes to specifications and product 0.834 design

\begin{tabular}{|c|c|c|c|c|c|}
\hline \multirow[t]{2}{*}{ Collaboration } & col1. Direct involvement of the company with its suppliers & 0.967 & \multirow[b]{2}{*}{0.917} & \multirow[b]{2}{*}{0.960} & \multirow[b]{2}{*}{0.923} \\
\hline & $\begin{array}{l}\text { logistics. } \\
\text { col2. Collaboration is maintained to enhance sustainability } \\
\text { performance. }\end{array}$ & 0.954 & & & \\
\hline \multirow{8}{*}{$\begin{array}{l}\text { Risk } \\
\text { Management }\end{array}$} & r1. Evaluate the acceptability of ingredients and working & 0.722 & \multirow{8}{*}{0.937} & \multirow{8}{*}{0.949} & \multirow{8}{*}{0.728} \\
\hline & conditions of member firms. & & & & \\
\hline & r2. Exercise informal supplier assessment. & 0.832 & & & \\
\hline & $\begin{array}{l}\text { r3. Standards are specified for the purchase of raw } \\
\text { materials. }\end{array}$ & 0.882 & & & \\
\hline & r4. There is early supplier involvement & 0.907 & & & \\
\hline & r5. Total quality management practices are implemented. & 0.884 & & & \\
\hline & $\begin{array}{l}\text { r6. Pressure groups are involved for their knowledge of } \\
\text { possible risks }\end{array}$ & 0.856 & & & \\
\hline & $\begin{array}{l}\text { r7. Top management focuses on customer quality needs in } \\
\text { setting strategy }\end{array}$ & 0.876 & & & \\
\hline \multirow[t]{11}{*}{ Proactivity } & $\begin{array}{l}\text { p1. Use new found knowledge for improving products and } \\
\text { processes }\end{array}$ & 0.814 & \multirow{11}{*}{0.951} & \multirow{11}{*}{0.960} & \multirow{11}{*}{0.750} \\
\hline & p2. Aware of stakeholder interests & 0.921 & & & \\
\hline & p3. Use new found knowledge for improving products and processes & 0.874 & & & \\
\hline & p4. Packing material is taken for re-use. & & & & \\
\hline & p5. Transparency maintained with stakeholders & 0.943 & & & \\
\hline & p6. Responsiveness to employees in making suggestions for & 0.756 & & & \\
\hline & quality improvement & 0.806 & & & \\
\hline & p7. Conduciveness of company environment to employee & & & & \\
\hline & wellbeing and growth is a concern & 0.941 & & & \\
\hline & p8. Employees are empowered on quality issues & & & & \\
\hline & & 0.854 & & & \\
\hline \multirow{3}{*}{$\begin{array}{l}\text { Environment } \\
\text { al }\end{array}$} & env1. Quantity of spillage. & 0.899 & \multirow{3}{*}{0.860} & \multirow{3}{*}{0.915} & \multirow{3}{*}{0.783} \\
\hline & env2. Quantity of non renewable energy resources used & 0.911 & & & \\
\hline & env3. Toxic discharges to water & 0.842 & & & \\
\hline \multirow[t]{5}{*}{ Social } & s1. Wage levels & 0.820 & \multirow{5}{*}{0.879} & \multirow{5}{*}{0.912} & \multirow{5}{*}{0.675} \\
\hline & s2. Healthcare benefits for employees & 0.809 & & & \\
\hline & s3. Number of accidents & 0.812 & & & \\
\hline & s4. Lost time injury frequency & 0.783 & & & \\
\hline & s5. Customer complaints & 0.880 & & & \\
\hline \multirow[t]{3}{*}{ Economic } & ec1. Return on assets and gearing & 0.959 & \multirow{3}{*}{0.896} & \multirow{3}{*}{0.937} & \multirow{3}{*}{0.832} \\
\hline & ec2. Average order fill lead time & 0.959 & & & \\
\hline & ec3. Market share. & 0.811 & & & \\
\hline \multirow[t]{2}{*}{ Contractual } & cg1. Rely on legal enforceability for restraining deviant & 0.935 & \multirow[b]{2}{*}{0.781} & \multirow[b]{2}{*}{0.899} & \\
\hline & $\begin{array}{l}\text { behavior of suppliers } \\
\text { cg2. Rely on monetary sanctions for restraining deviant } \\
\text { behavior of suppliers }\end{array}$ & 0.871 & & & 0.817 \\
\hline Relational & $\begin{array}{l}\text { rg1. Self enforceability of restraining opportunistic } \\
\text { behavior of suppliers. }\end{array}$ & 0.888 & & & \\
\hline & rg2. Relying on social sanctions for restraining deviant & 0.908 & & & \\
\hline & $\begin{array}{l}\text { behavior of suppliers. } \\
\text { r3. Re-adjustment/ renegotiation process that is cooperative and for mutual } \\
\text { benefit }\end{array}$ & 0.879 & 0.894 & 0.926 & 0.759 \\
\hline & $\begin{array}{l}\text { r4. Having exchange practices such as strategic information } \\
\text { exchange, asset specific investments, , supplier development, risk and } \\
\text { reward sharing and social interactions. }\end{array}$ & 0.806 & & & \\
\hline
\end{tabular}


Table 6. Discriminant Validity through the Fornell Larker Criteria

\begin{tabular}{|c|c|c|c|c|c|c|c|c|c|c|}
\hline & COL & CON & CONG & ECP & ENVP & ORI & PRO & RELG & RISM & SOCP \\
\hline COL & 0.960 & & & & & & & & & \\
\hline CON & 0.514 & 0.831 & & & & & & & & \\
\hline CONG & 0.382 & 0.406 & 0.904 & & & & & & & \\
\hline ECP & 0.501 & 0.570 & 0.652 & 0.912 & & & & & & \\
\hline ENVP & 0.489 & 0.744 & 0.342 & 0.587 & 0.885 & & & & & \\
\hline ORI & 0.524 & 0.694 & 0.572 & 0.881 & 0.777 & 0.862 & & & & \\
\hline PRO & 0.546 & 0.795 & 0.493 & 0.707 & 0.717 & 0.793 & 0.866 & & & \\
\hline RELG & 0.354 & 0.510 & 0.592 & 0.672 & 0.489 & 0.797 & 0.614 & 0.871 & & \\
\hline RISM & 0.506 & 0.591 & 0.286 & 0.581 & 0.596 & 0.684 & 0.729 & 0.522 & 0.853 & \\
\hline SOCP & 0.354 & 0.766 & 0.388 & 0.535 & 0.560 & 0.606 & 0.659 & 0.466 & 0.444 & 0.822 \\
\hline
\end{tabular}

6.2.1.2 Assessment of Higher Order Constructs

As the research involves exploring relationships at a higher level of abstraction, each second order construct (sustainable supply chain practices, supplier governance and sustainable performance) was assessed for its psychometric properties. Since the degree of explained variance of these constructs are reflected in the first order constructs this is a reflective hierarchical model. The repeated indicator approach was used to arrive at second order constructs (Akter et al., 2010).

In Table 7 the results show that the CRs \& AVEs of the second order model are greater than 0.80and 0.50 respectively, which provides evidence of reliable higher order measures.

Table 7. Psychometric Properties for Second Order Constructs

\begin{tabular}{lccc}
\hline Construct & Cronbach's Alpha & Composite Reliability & Average Variance Extracted (AVE) \\
\hline SUSGOV & 0.880 & 0.911 & 0.634 \\
SUSP & 0.911 & 0.925 & 0.529 \\
SUSPRAC & 0.972 & 0.974 & 0.556 \\
\hline
\end{tabular}

The model also revealed that all the first order constructs are reflective of the variances in the respective second order constructs. Orientation, continuity, collaboration, risk management and pro-activity explain 74\%, 79\%, $40 \%, 69 \%$ and $89 \%$ of the variance of sustainable supply chain practices respectively. Environmental performance, social performance and economic performance explain $68 \%, 74 \%$ and $67 \%$ of the variance of sustainable performance respectively. Contractual governance and relational governance explain $64 \%$ and $91 \%$ of the variance of supplier governance respectively. All the path coefficients from sustainable supply chain practices, sustainable performance and supplier governance to their first order constructs are significant at $\mathrm{P}<$ 0.01 as shown in Table 8 .

Table 8. Path Coefficients from Second Order Constructs to First Order Constructs

\begin{tabular}{lccc}
\hline & Path Coefficient & T Statistics & P Values \\
\hline SUSGOV -> CONG & 0.804 & 24.799 & 0.000 \\
SUSGOV -> RELG & 0.955 & 140.803 & 0.000 \\
SUSP -> ECP & 0.824 & 28.747 & 0.000 \\
SUSP -> ENVP & 0.828 & 25.210 & 0.000 \\
SUSP -> SOCP & 0.865 & 32.539 & 0.000 \\
SUSPRAC -> COL & 0.637 & 12.851 & 0.000 \\
SUSPRAC -> CON & 0.889 & 47.393 & 0.000 \\
SUSPRAC -> ORI & 0.863 & 37.097 & 0.000 \\
SUSPRAC -> PRO & 0.944 & 137.745 & 0.000 \\
SUSPRAC -> RISM & 0.834 & 28.901 & 0.000 \\
\hline
\end{tabular}

6.2.2 Assessment of Structural Model

The predictive capability and the relationships between the constructs were assessed through the structural model. This exercise was carried out only after an examination of the structural model for collinearity. Based on VIF values it revealed that there isn't significant levels of collinearity among the predictor constructs.

It can be seen from the model estimates that the proposed model shows a high explanatory power (through determination coefficient, $\mathrm{R}^{2}$ ) for sustainable performance (0.841). The results showing a good explanatory power and provide strong support for the nomological validity of the proposed model.

Since the structural model contained a moderator variable the assessment involved both the direct and interaction effects. When the model was assessed for direct effects the path coefficients from sustainable supply chain practices to sustainable performance and from supplier governance to sustainable performance indicated standardized beta values of 0.820 and 0.123 respectively, representing the hypothesized relationships among the constructs. These path coefficients were significant at $\mathrm{p}<0.01$ (Table 9) thus providing evidence that both 
sustainable supply chain practices and supplier governance have direct impacts of $82 \%$ and $12 \%$ respectively on sustainable performance. With this evidence of a significant, positive impact of both sustainable supply chain practices and supplier governance on sustainable performance, $\mathrm{H} 1$ and $\mathrm{H} 2$ were supported.

Table 9. Path Coefficients of Direct Effects in the Structural Model

\begin{tabular}{lccc}
\hline & Path Coefficient & T Statis tics & P Values \\
\hline SUSGOV -> SUSP & 0.123 & 2.289 & 0.023 \\
SUSPRAC -> SUSP & 0.820 & 18.315 & 0.000 \\
\hline
\end{tabular}

Moderating effects are evoked by variables whose variation influences the strength or the direction of a relationship between an exogenous and an endogenous variable (Henseler and Fassott, 2010, Henseler and Chin, 2010). In the present study the researcher attempted to identify how the variation in supplier governance influences the strength of the relationship between sustainable supply chain practices and sustainable performance. The descriptive statistics showed that supplier governance is practiced at a higher level in the apparel manufacturing and exporting industry of Sri Lanka. When an interaction term was introduced to the model to assess the moderation effect of supplier governance a standardized beta value of -0.073 was obtained. This implies that if the level of supplier governance gets higher the relationship between sustainable supply chain practices and sustainable performance would decrease by the size of the interaction term. In other words the initial relationship will decrease by 0.073 and the strength of the relationship will decrease to 0.742 (0.825-0.073).Since such conclusions hold only when the interaction term is significant a bootstrapping procedure was run to find the t-value which gave a value of 5.068 indicating that the finding is significant. Although this path coefficient was statistically significant the relationship was in the opposite direction to what was hypothesized. For firms that practiced more supplier governance, the relationship between sustainable supply chain practices and sustainable performance was found weaker. Hypothesis 3 (H3) has to be rejected with this result.

Table 10. Path Coefficients of the Interaction Effect in the Structural Model

\begin{tabular}{lccc}
\hline & Path Coefficient & T Statistics & P Values \\
\hline Moderating Effect 1 -> SUSP & -0.073 & 5.007 & 0.000 \\
SUSGOV -> SUSP & 0.101 & 2.010 & 0.045 \\
SUSPRAC $->$ SUSP & 0.825 & 18.326 & 0.000 \\
\hline
\end{tabular}

6.2.3 Overall Assessment of the Model

Instead of applying measures of goodness of fit, the structural model in PLS SEM is assessed on the basis of heuristic criteria that are determined by the model's predictive capabilities (Hair et al., 2012, 2013, Henseler et al.,2015,2016). In other words the model is assessed in terms of how well it predicts the endogenous constructs. Therefore the key criteria for assessing the structural model in PLS SEM, are the significance of the path coefficients, level of $\mathrm{R}^{2}$ values, the $\mathrm{f}^{2}$ effect size and the predictive relevance $\left(\mathrm{Q}^{2}\right)$.

The most commonly used measure to evaluate the structural model is the coefficient of determination $\left(\mathrm{R}^{2}\right)$. It indicates the model's predictive accuracy and the variance in the endogenous construct explained by all of the exogenous constructs linked to it. In the present study the predictive accuracy is high with $84.1 \%$ variance in sustainable performance being explained by sustainable supply chain practices and supplier governance.The effect sizes for evaluating the predictive importance of each determinant were 0.034 and 2.316 respectively for supplier governance and sustainable supply chain practices indicating a small effect and a large effectof the two variables on sustainable performance. Further, the predictive relevance of the exogenous constructs for the endogenous construct in the model was established with a $Q^{2}$ value of 0.377 .

\section{Discussion \& Implications}

The results of PLS modeling support two of the hypotheses while rejecting the hypothesis that tested the moderation effect of supplier governance. This brought about an important contribution to the theoretical knowledge in relation to the outcomes of governance when it is applied to suppliers in the context of sustainable performance of manufacturing firms in developing countries.

TCT argues that exchange conditions have varying le vels of costs associated with establishing and maintaining a relationship. Firms that are able to match the governance structure with the exchange context perform better (Grover and Saeed, 2007). The underlying argument here is that although opportunism increases where parties invest asymmetrically in an exchange the relation of comparative commitment and opportunism may be moderated by various governance safeguards (Lusch and Brown,1996). It is with this understanding that the researcher expected a positive moderating influence of supplier governance on the relationship between the sustainable supply chain practices of the manufacturers in the apparel exporting industry of Sri Lanka and their 
sustainable performance. But Hypothesis 3 (H3) which was de veloped to test this relationship was not supported by the empirical data. Rather it was showing results in the opposite direction.

The application of governance mechanisms in the apparel manufacturing and exporting industry was tested in terms of relational governance and contractual governance which were identified as hybrid governance mechanisms by Cai et al. (2009). According to them quasi integration between organizations should allow them to access resources from one another, including information knowledge to support transaction and innovation, resolve differences between two parties, coordinate activities of two parties to handle environmental uncertainty, improve performance and promote innovation and protect transaction specific investments (TSI) in achieving better results. The existence of both relational and contractual governance were identified as important by the authors since in a highly competitive relationship one should not expect that all disputes can be resolved through such a process whereby the buyer and the supplier work together to settle their differences. Lusch and Brown (1996) also supported this idea when they explain that utility of safeguards that rely on the power of social conformity and sanctions have been questioned since social standards tend to be broadly defined and are subject to varying interpretations and can be manipulated to the advantage of one party thus highlighting the importance of both relational and contractual governance. Cannon et al. (2000) refers to this hybrid structure of governance as plural form of governance. They explain that when the governance structure involves more relational content it makes easy to bring better performance outcomes from contractual governance. Contractual governance is necessary as a mechanism that serves as a broad structural framework for the relationship. The results show that performance suffers when detailed contracts are used without a well-developed social relationship to govern exchanges involving high transactional uncertainty.

But Cannon et al. (2000) explain that while interdependence motivates companies to develop complicated contracts between them, such contracts are often expensive to draft and cover all possible future contingencies so that the parties to an exchange tend to rely more on relational governance elements to safeguard the relationship. As a result the plural governance mechanisms that bring positive outcomes to the exchange parties does not take place all the time.

In the apparel manufacturing and exporting industry of Sri Lanka the researcher could identify the practice of both relational and contractual governance. However in explaining total supplier governance in the measurement model, relational governance explained $91 \%$. But as explained in previous literature the outcomes of relational governance are relatively weaker than the contractual governance although they bring positive results in combination. Sri Lanka being a developing nation the manufacturers are unable to spend large amounts on contracts and therefore they are heavily dependent on the suppliers who are recommended by their customers. This fact was revealed in the in depth interviews with the representatives of the manufacturing firms. The re ason for not getting the expected results for $\mathrm{H} 3$ might be due to the fact that relational governance could not bring better outcomes for the exchange parties since the optimal level of contractual governance was not present to bring the positive outcome.

But in contrast to this finding Cai et al. (2009) suggest that increasing the relational content of a governance structure alone results in enhanced performance for relationships involving both high levels of transactional uncertainty as well as low levels of uncertainty. They argue that joint planning, joint problem solving and collaborative communication are important elements of relational governance and if the relational governance is confined merely to problem solving the expected improvements in performance are less likely. The position in the apparel manufacturing and exporting industry of Sri Lanka could be similar in nature where the supplier governance is not supporting the relationship between the sustainable supply chain practices of the organizations in the apparel manufacturing and exporting industry of Sri Lanka and their sustainable performance. This has to be further studied since the questionnaire items used in the present study did not directly question the practice of joint problem solving. An important fact here is that relational governance is said to bring positive outcomes only when the relational content is increased alone. But in the Sri Lankan context both contractual and relational governance is practiced.

There is also a completely different argument which highlights that when environments are more certain or tasks involve little ambiguity, with few relationship specific adaptations, future contingencies can be projected with greater accuracy and addressed more precisely in a written agreement. There is little need to modify contracts or rely on other safeguards under such conditions. Therefore when the exchanges involve low levels of transactional uncertainty enhanced performance does not occur by coupling contractual governance and relational content. By relating these explanations what the researcher could infer from the findings is that the firms in the apparel manufacturing and exporting industry of Sri Lanka may be exposed to a more certain exchange environment where future contingencies can be projected with greater accuracy, less ambiguity is 
present and few relationship specific adaptations exist where relational norms become unnecessary. The suppliers with whom these manufacturing firms deal with are specified by the customers. Therefore it is reasonable to assume that the abo ve characteristics are prevalent in the exchanges that are formed by the apparel manufacturing and exporting firms in Sri Lanka with their suppliers. Literature suggests that contractual governance would be sufficient to obtain better outcomes under such circumstances. This might have been a possible reason for the negative moderating effect of supplier governance on the relationship between the sustainable supply chain practices and sustainable performance of firms in the apparel manufacturing and exporting industry of Sri Lanka since they adopted a plural go vernance mechanism with relational governance at a comparatively higher level.

\section{Conclusion}

Organizations in the apparel manufacturing and exporting industry of Sri Lanka have suppliers of material and accessories with whom they build relationships in delivering a valued product to their customers. These organizations are compelled to engage in sustainable production to satisfy the requirements of the ir stake holders. Governance is a strategy suggested in literature that helps firms to bring better exchange outcomes. Therefore the researcher expected that by exercising supplier governance the manufacturers could improve the relationship between sustainable supply chain practices and sustainable performance. However the data collected from 154 firms in the industry revealed that this logic does not hold true in the apparel manufacturing and exporting industry of Sri Lanka. With the arguments presented in literature researcher concluded that a plural mechanism of governance may not be a suitable one for supplier governance of these firms. The environment they face can be assumed to be much certain since there are less chances of adaptation and less ambiguity in the exchange relationship when much of the exchanges with suppliers are explained and detailed by the customer who is at the other end of the supply chain. There is also a possibility that the method used to analyze performance and relational governance mechanisms in this particular study and those of others is different and therefore the finding of different studies were not of similar nature to clearly confirm the existing theory.

\section{References}

Afthanorhan, W. M. A. B. W. (2013). A comparison of partial least square structural equation modeling (PLS-SEM) and covariance based structural equation modeling (CB-SEM) for confirmatory factor analysis. International Journal of Engineering Science and Innovative Technology, 2(5), 198-205. http://www.ijesit.com/Volume\%202/Issue\%205/IJESIT201305_27.pd

Akter, S., D’Ambra, J., \& Ray, P. (2010). Service quality of mHealth platforms: development and validation of a hierarchical model using PLS. Electronic Markets, 20(3-4), 209-227. https://doi.org/10.1007/s12525-010-0043-x

Beske, P., \& Seuring, S. (2014). Putting sustainability into supply chain management. Supply Chain Management: An International Journal, 19(3), 322-331. https://doi.org/10.1108/SCM-12-2013-0432

Bitran, G. R., Gurumurthi, S., \& Sam, S. L. (2006). Emerging trends in supply chain governance. https://doi.org/10.2139/ssrn.882086

Blandine, A., Gunasekaran, A., \& Alain, S. (2012). Sustainable supply management: An empirical study. International Journal of Production Economics, 140(1). https://econpapers.repec.org/RePEc:eee:proeco:v:140:y:2012:i:1:p:168-182

Bollen, K. (2002). Latent Variables in Psychology and the Social Sciences. Annu. Rev. Psychol, 53, 605-634. https://doi.org/10.1146/annurev.psych.53.100901.135239

Bollen, K., \& Lennox, R. (1991). Conventional wisdom on measurement: A structural equation perspective. Psychological bulletin, 110(2), 305. https://doi.org/10.1037/0033-2909.110.2.305

Brammer, S., \& Millington, A. (2008). Does it pay to be different? An analysis of the relationship between corporate social and financial performance. Strategic Management Journal, 29(12), 1325-1343. https://doi.org/10.1002/smj.714

Cai, S., Yang, Z., \& Hu, Z. (2009). Exploring the governance mechanisms of quasi-integration in buyer-supplier relationships. Journal of Business Research, 62(6), 660-666. https://doi.org/10.1016/j.jbusres.2008.02.004

Cannon, J. P., Achrol, R. S., \& Gundlach, G. T. (2000). Contracts, norms, and plural form governance. Journal of the Academy of Marketing Science, 28(2), 180-194. https://doi.org/10.1177/0092070300282001

Cao, M., \& Zhang, Q. (2011). Supply chain collaboration: Impact on collaborative advantage and firm performance. Journal of operations management, 29(3), 163-180. https://doi.org/10.1016/j.jom.2010.12.008 
Carey, S., \& Lawson, B. (2011). Governance and social capital formation in buyer-supplier relationships. Journal of Manufacturing Technology Management, 22(2), 152-170. https://doi.org/10.1108/17410381111102199

Carter, C. R., \& Rogers, D. S. (2008). A framework of sustainable supply chain management: moving toward new theory. International journal of physical distribution \& logistics management, 38(5), 360-387. https://doi.org/10.1108/09600030810882816

Chin, W. W. (1998). The partial least squares approach to structural equation modeling. Modern methods for business research, 295(2), 295-336. [Online]. Available at https://books.google.lk/

Chuah, P., Peng Wong, W., Ramayah, T., \& Jantan, M. (2010). Organizational context, supplier management practices and supplier performance: A case study of a multinational company in Malaysia. Journal of Enterprise Information Management, 23(6), 724-758. https://doi.org/10.1108/17410391011088619

Cox, A., Watson, G., Lonsdale, C., \& Sanderson, J. (2004). Managing appropriately in power regimes: relationship and performance management in 12 supply chain cases. Supply Chain Management: An International Journal, 9(5), 357-371. https://doi.org/10.1108/13598540410560748

Cronbach, L. J. (1951). Coefficient alpha and the internal structure of tests. psychometrika, 16(3), 297-334. https://doi.org/10.1007/BF02310555

Espallardo, M. H., Orejuela, A. R., \& Pérez, M. S. (2010). Inter-organizational Governance, Learning and Performance in Supply Chains. Supply Chain Management: An International Journal, 15(2), 101-114. https://doi.org/10.1108/13598541011028714

Fornell, C., \& Larcker, D. F. (1981). Structural equation models with unobservable variables and measurement error: Algebra and statistics. Journal of marketing research, 382-388. https://doi.org/10.2307/3150980

Gefen, D., \& Straub, D. (2005). A practical guide to factorial validity using PLS-Graph: Tutorial and annotated example. Communications of the Association for Information systems, 16(1), 5. http://aisel.aisnet.org/cais/vol16/iss 1/5

Golicic, S. L., \& Smith, C. D. (2013). A meta - analysis of environmentally sustainable supply chain management practices and firm performance. Journal of supply chain management, 49(2), 78-95. https://doi.org/10.1111/jscm.12006

Granovetter, M. (1985). Economic Action and Social Structure: The Problem of Embededdness, American Journal of Sociology, 91(3), 481-510. https://doi.org/10.1086/228311

Grover, V., \& Saeed, K. A. (2007). The Impact of Product, Market and Relationship Characteristics on Inter organizational System Integration in Manufacturer Supplier Dyads. Journal of Management Information Systems, 23(4), 185-216. https://doi.org/10.2753/MIS0742-1222230409

Hair Jr, J. F., Hult, G. T. M., Ringle, C., \& Sarstedt, M. (2016). A primer on partial least squares structural equation modeling (PLS-SEM). https://doi.org/10.1080/1743727X.2015.1005806

Hair, J. F., Ringle, C. M., \& Sarstedt, M. (2012). Partial least squares: the better approach to structural equation modeling? https://papers.ssrn.com/soL3/papers.cfm?abstract_id=2227601

Hair, J. F., Ringle, C. M., \& Sarstedt, M. (2013). Partial least squares structural equation modeling: Rigorous applications, better results and higher acceptance. https://doi.org/10.1016/j.lrp.2013.01.001

Hair, J. F., Sarstedt, M., Pieper, T. M., \& Ringle, C. M. (2012). The use of partial least squares structural equation modeling in strategic management research: a review of past practices and recommendations for future applications. Long range planning, 45(5), 320-340. https://doi.org/10.1016/j.lrp.2012.09.008

Henseler, J., \& Chin, W. W. (2010). A comparison of approaches for the analysis of interaction effects between latent variables using partial least squares path modeling. Structural Equation Modeling, 17(1), 82-109. https://doi.org/10.1080/10705510903439003

Henseler, J., \& Fassott, G. (2010). Testing moderating effects in PLS path models: An illustration of available procedures. In Handbook of partial least squares, 713-735. https://doi.org/10.1007/978-3-540-32827-8_31

Henseler, J., Hubona, G., \& Ray, P.A. (2016). Using PLS path modeling in new technology research: updated guidelines. Industrial management \& data systems, 116(1), 2-20. https://doi.org/10.1108/IMDS-09-2015-0382

Henseler, J., Ringle, C. M., \& Sarstedt, M. (2015). A new criterion for assessing discriminant validity in variance-based structural equation modeling. Journal of the Academy of Marketing Science, 43(1), 115-135. 
https://doi.org/10.1007/s11747-014-0403-8

Hubbard, G. (2009). Measuring Organizational Performance: Beyond the Triple Bottom Line. Business Strategy and the Environment, 18, 177-191. https://doi.org/10.1002/bse.564

Jarvis, C. B., MacKenzie, S. B., \& Podsakoff, P. M. (2003). A critical review of construct indicators and measurement model misspecification in marketing and consumer research. Journal of consumer research, 30(2), 199-218. https://doi.org/10.1086/376806

Krause, D. R., \& Ellram, L. M. (1997). Success factors in supplier development. International Journal of Physical Distribution\& Logistics Management, 27(1),39-52.https://doi.org/10.1108/09600039710162277

Law, K. S., Wong, C. S., \& Mobley, W. H. (1998). Toward a Taxonomy of Multidimensional Constructs. Academy of Management Review, 23(4), 741-755. http://amr.aom.org/content/23/4/741.short

Liker, J. K., \& Choi, T. Y. (2006). Building Deep Supplier Relationships. .Harvard Business Review on Supply Chain Management.

Lusch, R. F., \& Brown, J. R. (1996). Interdependency, contracting, and relational behavior in marketing channels. The Journal of Marketing, 19-38. https://doi.org/10.2307/1251899

Mellewigt, T., Madhok, A., \& Weibel, A. (2007).Trust and Formal Contracts in Inter-organizational Relationships - Substitutes and Complements. Managerial and Decision Economics, 28(8) (Dec., 2007), 833-847. https://doi.org/10.1002/mde.1321

Moretto, A. et. al. (2012). Sustainability in the Fashion Industry: An Important Source of Supply Chain Innovation, Decision Sciences Institute $43{ }^{\text {rd }}$ Annual Conference, www.research.allacademic.com

Mulaik, S. A. (2009). Foundations of factor analysis. CRC press, Mulaik, CRC press, books.google.com

Nahapiet, J., \& Ghoshal, S. (1998). Social Capital, Intellectual Capital, and the Organizational Advantage. The Academy of Management Review, 23(2), 242-266, Published by: Academy of Management, http://amr.aom.org/content/23/2/242.short

Pfeffer, J., \& Salanick, G. R. (2003). The External Control of Organizations. Stanford University Press, books.google.com

Poppo, L., \& Zenger, T. (2002). Do Formal Contracts and Relational Governance Function as Substitutes or Complements? Strategic Management Journal, 23, 707-725. https://doi.org/10.1002/smj.249

Rao, P., \& Holt, D. (2005). Do green supply chains lead to competitiveness and economic performance? International Journal of Operations \& Production Management, 25(9), 898-916. https://doi.org/10.1108/01443570510613956

Reuter, C., Foerstl, K. A. I., Hartmann, E. V. I., \& Blome, C. (2010). Sustainable global supplier management: the role of dynamic capabilities in achieving competitive advantage. Journal of Supply Chain Management, 46(2), 45-63. https://doi.org/10.1111/j.1745-493X.2010.03189.x

Rose, S., Spinks, N., \& Canhoto, A. I. (2014). Management research: Applying the principles. books.google.com

Rowley, T., Behrens, D., \& Krackhardt, D. (2000). Redundant go vernance structures: an analysis of structural and relational embeddedness in the steel and semiconductor industries. Strategic Management Journal, 21(3), 369-386. https://doi.org/10.1002/(SICI) 1097-0266(200003)21:3<369::AID-SMJ93>3.0.CO;2-M

Schaltegger, S., \& Burritt, R. (2014). Measuring and managing sustainability performance of supply chains: Review and sustainability supply chain management framework. Supply Chain Management: An International Journal, 19(3), 232-241. https://doi.org/10.1108/SCM-02-2014-0061

Seuring, S., \& Müller, M. (2008). From a literature review to a conceptual framework for sustainable supply

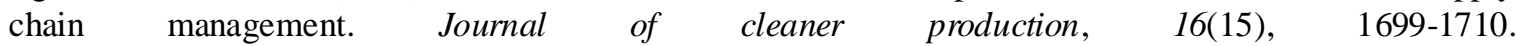
https://doi.org/10.1016/j.jclepro.2008.04.020

Verdecho, M. J., Alfaro-Saiz, J. J., \& Rodriguez-Rodriguez, R. (2012). A performance measurement framework for monitoring supply chain sustainability. 6th International Conference on Industrial Engineering and Indusrial Management. XVI Congreso de Ingeniería de organización. Vigo, July 18-20, [Online]. Available at adingor.es

Wathne, K. H., \& Heide, J. B. (2004). Relationship Governance in a Supply Chain Network. Journal of Marketing, 68(1), 73-89. Published by American Marketing Association. https://doi.org/10.1509/jmkg.68.1.73.24037 
Wetzels, M., Odekerken-Schröder, G., \& Van Oppen, C. (2009). Using PLS path modeling for assessing hierarchical construct models: Guidelines and empirical illustration. MIS quarterly, 177-195. http://www.jstor.org/stable/20650284?seq=1\#page_scan_tab_contents

Williamson, O. E. (1993). Opportunism and Its Critics. Managerial and Decision Economics, 14(2), Special Issue: Transactions Costs Economics (Mar. - Apr., 1993), 97-107. https://doi.org/10.1002/mde.4090140203

Wilson, B. (2010). Using PLS to investigate interaction effects between higher order branding constructs. In Handbook of partial least squares, 621-652, Springer Berlin Heidelberg. https://doi.org/10.1007/978-3-540-32827-8_28

Zhao, X., Huo, B., Flynn, B. B., \& Yeung, J. H. Y. (2008). The Impact of Power and Relationship Commitment on The Integration Between Manufacturers and Customers In a Supply Chain. Journal of Operations Management, 26, 368-388. https://doi.org/10.1016/j.jom.2007.08.002

\section{Copyrights}

Copyright for this article is retained by the author(s), with first publication rights granted to the journal.

This is an open-access article distributed under the terms and conditions of the Creative Commons Attribution license (http://creativecommons.org/licenses/by/4.0/). 